\title{
Chemical composition and sensory profile of Syrah wines from semiarid tropical Brazil - Rootstock and harvest season effects
}

\author{
Juliane Barreto de Oliveira $^{\mathrm{a}, *}$, Ricardo Egipto ${ }^{\mathrm{a}, \mathrm{b}}$, Olga Laureano ${ }^{\mathrm{a}}$, Rogério de Castro ${ }^{\mathrm{a}}$, \\ Giuliano Elias Pereira ${ }^{c}$, Jorge Manuel Ricardo-da-Silva ${ }^{a}$ \\ ${ }^{\mathrm{a}}$ LEAF- Linking Landscape, Environment, Agriculture and Food. Instituto Superior de Agronomia, Universidade de Lisboa, Tapada da Ajuda, 1349-017, Lisbon, Portugal \\ ${ }^{\mathrm{b}}$ INIAV, I.P., Pólo de Dois Portos, Quinta da Almoínha, 2565-191, Dois Portos, Portugal \\ ${ }^{\mathrm{c}}$ Brazilian Agricultural Research Corporation - Embrapa Grape \&Wine, Rua Livramento 515, CP 130, 95.701-008, Bento Gonçalves-RS, Brazil
}

\section{A R T I C L E I N F O}

\section{Keywords:}

Phenolic compounds

Red wines

Vitis vinifera $\mathrm{L}$.

Sensory

Tropical region

\begin{abstract}
A B S T R A C T
This study aims to characterise the chemical compositions and sensorial profiles of wines made with Syrah grapes over two harvest seasons (first and second semester), over in different calendar years, from vines on two different rootstocks (1103P and IAC 313). Wine chemical composition and sensory profile were influenced by both rootstock and harvest season. Syrah wines on IAC 313 were favoured with higher concentrations of, petunidin 3-O-acetylglucoside $(3.7 \mathrm{mg} / \mathrm{L})$, malvidin 3 - $O$-acetylglucoside $(17.8 \mathrm{mg} / \mathrm{L})$, malvidin 3-O-coumarylglucoside $(4.4 \mathrm{mg} / \mathrm{L})$, petunidin 3 - $O$-coumarylglucoside $(2.0 \mathrm{mg} / \mathrm{L})$, peonidin 3 - $O$-coumarylglucoside $(1.4 \mathrm{mg} /$ $\mathrm{L})$, monomeric flavanols $(23.6 \mathrm{mg} / \mathrm{L})$, oligomeric tannins $(183.0 \mathrm{mg} / \mathrm{L})$, total condensed tannins $(1037.7 \mathrm{mg} / \mathrm{L})$, dimer B1 $(9.8 \mathrm{mg} / \mathrm{L})$, B4 $(5.0 \mathrm{mg} / \mathrm{L})$, trimer C1 $(3.1 \mathrm{mg} / \mathrm{L})$ and calcium $(80 \mathrm{mg} / \mathrm{L})$. Syrah wines on 1103P had higher concentrations of total anthocyanins $(375.6 \mathrm{mg} / \mathrm{L}$, catechin $(8.6 \mathrm{mg} / \mathrm{L})$, epicatechin $(12.6 \mathrm{mg} / \mathrm{L})$, dimer B2 $(21.0 \mathrm{mg} / \mathrm{L})$, B1 3-O-gallate $(1.8 \mathrm{mg} / \mathrm{L})$, B2 3 - $O$-gallate $(6.0 \mathrm{mg} / \mathrm{L})$ and total flavanols $(53.4 \mathrm{mg} / \mathrm{L})$. The sensory profiles of the Syrah wines were influenced by rootstock followed by, mainly in relation to aromatic attributes. Syrah wines on IAC 313 were scored more highly by the tasters.
\end{abstract}

\section{Introduction}

Wine quality is determined as a combination of a large number of factors. Among these, are a range of 'vineyard' factors which affect the physicochemical composition of the grapes and thus of the resulting wines. These vineyard factors include: the soil, the weather, canopy management, rootstock, irrigation management (Xu et al., 2015). A number of studies in different regions have compared the effects of different rootstocks on wine quality. These identified significant rootstocks effects on wine composition: anthocyanin profile and potassium concentration in Washington (Harbertson \& Keller, 2012), volatile compounds and free amino acids in California (Ough, Cook, \& Lider, 1968), total polyphenols in Montenegro (Maraš, Kodžulović, Raičević, Gazivoda, \& Perišić, 2016) and anthocyanins and flavanols in Australia and Italy (Mantilla et al., 2017; Suriano et al., 2016).

Traditional winegrowing regions range from warm temperate to cool temperate and these allow only a single crop each year. However, viticulture is also practiced in some tropical regions where seasonal minimum temperatures are not low enough to induce vine dormancy. Here, the vines grow continuously and, with the appropriate interventions, are able to produce two or more harvests per year on the same vines.

The São Francisco River Valley is a tropical, semiarid region of Brazil. Here, viticulture normally extends over two semesters each calendar year - from approximately May to August (semester 1) and from approximately October to December (semester 2). Depending on which semester, the wines vary greatly in composition, quality and typicality, mainly due to intra-annual weather variability (Pereira, Araújo, Santos, Vanderlinde, \& Lima, 2011). The region is located between parallels 8 and $10^{\circ} \mathrm{S}$ and is characterised by an annual average temperature of $26.5^{\circ} \mathrm{C}$ and about $3000 \mathrm{~h}$ of sunshine per year (Pereira et al., 2018). The cultivar Vitis vinifera L. Syrah is the main red grape for wine production in this region of northeast Brazil.

The "sub-middle" of the São Francisco River Valley is a very important viticultural region. Hence, it is important to understand the influences of the various viticultural techniques used in this tropical region on the quality of the resulting grapes and wines. The aim of this study was to characterise the chemical compositions and sensory profiles of wines made with $\mathrm{cv}$. Syrah (Vitis vinifera L.) during four growth periods - two in the first semester and the others in the second semester.

\footnotetext{
* Corresponding author.

E-mail address: juliane.barreto@hotmail.com (J.B.d. Oliveira).
} 
The wines were made with grapes from vines grafted on one or other of two rootstocks IAC 313 and 1103P. Here, for the first time, it was used an analytical approach to separation and quantify, understand how different kinds of condensed tannins and other chemical components in the wines were affected by the two growth harvest seasons and by the two rootstocks, in this tropical viticulture conditions.

\section{Material and methods}

\subsection{Chemicals and standards}

Analytical grade methanol, diethyl ether, ethyl acetate, acetic acid, acetone were purchased from Fisher Scientific (Loughborough, United Kingdom). Pure standards of $(+)$-catechin, $(-)$-epicatechin, B2 dimer, malvidin-3-O-glucoside, and gallic acid were acquired from Extrasynthese (Genay, France). Ethanol, formic acid, acetonitrile, acetaldehyde, and formaldehyde were bought from Honeywell (Seelze, Germany). The vanillin, sodium metabisulfite, sodium hydroxide, tartaric acid, potassium hydroxide, methanol, bovine albumin, and sulphuric acid, were of the Sigma-Aldrich (St. Louis, USA). Also used were purified Polyamid DC 6 also referred as TLC 6 (Macherey-Nagel, Düren, Germany).

\subsection{Characterisation of vineyards and grapes}

The work was carried out in experimental vineyards belonging to a partner winery, Santa Maria/Global wines, located in the municipality of Lagoa Grande, Pernambuco, Brazil, at latitude 8 to $9^{\circ} 02^{\prime} \mathrm{S}$ and longitude $40^{\circ} 11^{\prime} \mathrm{W}$, at an altitude of $350 \mathrm{~m}$. Most soils are podzols. The Syrah grapevines were grafted onto IAC 313 or Paulsen 1103P rootstocks, managed as a vertical trellis, vine spacing was $3.0 \times 1.0 \mathrm{~m}$, with north-south row orientation, with a reasonably homogeneous soil, and in the first year of the study the vines had 10 years. The vineyards were drip irrigated with the same volume of water applied to all the treatments of rootstock in the same day. The optimal harvest time was determined by the company on the basis of ${ }^{\circ} \mathrm{Brix}$, total acidity and $\mathrm{pH}$. The composition of the grapes at harvest is shown in (Table 2, supplementary material).

Approximately $40 \mathrm{~kg}$ of grapes was collected from each of a number of previously, randomly-selected vines. The evaluation of grapes was carried out over four harvests, the first harvest was in December 2014 (semester 2), the second in July 2016 (semester 1), the third in January 2016 (semester 2) and the fourth in July 2017 (semester 1).

\subsection{Vinification of monovarietal wines}

Wines were made using traditional vinification methods but at experimental scale with each grape sample being of $40 \mathrm{~kg}$. Stems were removed using semi-automatic equipment (Model DH150-DA, Ricefer, Garibaldi, Brazil), then $50 \mathrm{mg} / \mathrm{L}$ of sulphur dioxide and $20 \mathrm{~g} / \mathrm{hL}$ of yeast (Saccharomyces cerevisiae, var. bayanus, Ever intec, Venezia, Italy) were added for alcoholic fermentation which occurred at temperatures between 22 and $25^{\circ} \mathrm{C}$, the remontage was carried out once a day in rack and return mode. Maceration time (uniform across all treatments) was for 7 days to maintain uniform the extraction of phenolics. The end of alcoholic fermentation was identified by the stability of the values of density and alcohol content. Malolactic fermentation was made without addition of lactic acid bacteria, using only the native species, with temperatures varying between 16 and $18^{\circ} \mathrm{C}$. the end point was identified using paper chromatography (OIV, 2014). Tartaric stabilisation in the cold $\left(0-5{ }^{\circ} \mathrm{C}\right)$ was for 30 days, sulphur dioxide was corrected and wines were bottled with nitrogen and stored in the cellar at $16 \pm 2{ }^{\circ} \mathrm{C}$.

\subsection{Physical-chemical characterisation of wines}

Wines were analysed after six months for the classic parameters, besides the potassium and calcium. The methodology was based on the International Organisation of Vine and Wine (OIV, 2014).

Colorimetric parameters were analysed as follows: total anthocyanins (Ribéreau-Gayon \& Stonestreet, 1965); coloured anthocyanin; total and polymeric pigments (Somers \& Evans, 1977); total phenols (Ribéreau-Gayon, 1970); flavonoids and non-flavonoids (Kramling \& Singleton, 1969); colour co-pigmentation (Boulton, 2001); colour intensity and tonality (OIV, 2014); tanning power (de Freitas \& Mateus, 2001).

Separation and quantification of monomeric anthocyanins were made directly in a filtered wine sample, as described by Roggero, Coen, and Ragonnet (1986), using a HPLC (PerkinElmer, San Francisco, USA), consisting for a pump Series 200 and detector LC95 Uv/Visible, a column C18 $(250 \mathrm{~mm} \times 4 \mathrm{~mm})$, with reverse phase of $5 \mu \mathrm{m}$ of compaction, protected by a pre-column of the same material (LichroCart, Merck, Darmstadt, Germany). The solvents were: A $(40 \mathrm{~mL}$ formic acid and $60 \mathrm{~mL}$ bi-distilled water), B (acetonitrile PA) and C (bidistilled water). Methanol:water $(50: 50 \mathrm{~mL} / \mathrm{mL})$ was used to wash the column after the analyses. The initial conditions used were: $25 \% \mathrm{~A}, 6 \% \mathrm{~B}$ and $69 \%$ C for $15 \mathrm{~min}$, followed by a $25 \%$ linear gradient of A, $25.5 \%$ B and $49.5 \%$ C for $70 \mathrm{~min}$. Finishing with $20 \mathrm{~min}$ of $25 \%$ A $25.5 \%$ B and $49.5 \% \mathrm{C}$. The flow was $0.7 \mathrm{~mL} / \mathrm{min}$, using a detector with wavelength at $520 \mathrm{~nm}$. Both the samples and the solvents were filtered under the same conditions. The volume injected was $20 \mu \mathrm{L}$ and the analyses were carried out in triplicate. Quantification of fourteen individual anthocyanin molecules was based in a standard curve using malvidin 3-Oglucoside as the internal standard.

Fractionation of low molecular weight flavanols was by polyamide column chromatography and further quantification was by HPLC following the method of Ricardo-da-Silva, Rosec, Bourzeix, and Heredia (1990). Identification of compounds followed the method of Ricardoda-Silva, Rigaud, Cheynier, Cheminat, and Moutounet (1991) and Rigaud, Pérez-Ilzarbe, Ricardo-da-Silva, and Cheynier (1991) and was confirmed using the method of Monagas, Gómez-Cordovés, Bartolomé, Laureano, and Ricardo-da-Silva (2003). The HPLC equipment comprised a UV-Vis detector Waters 2487 (Milford, USA) and a pump Merck L-7100 (Darmstadt, Germany). The separation was carried out on a Lichrosphere C18 reverse phase column (Merck, Darmstadt, Germany) $250 \mathrm{~mm} \times 4.6 \mathrm{~mm} \times 5 \mu \mathrm{m}$, at ambient temperature. For monomeric flavan-3-ols, a gradient consisting of solvent A (water: acetic acid, 97.5:2.5, mL/mL) and solvent B (acetonitrile/solvent A, $80: 20 \mathrm{~mL} / \mathrm{mL}$ ) was applied at a flow rate of $0.9 \mathrm{~mL} / \mathrm{min}$ as: $7-25 \% \mathrm{~B}$ linear from 0 to $31 \mathrm{~min}$, followed by washing (methanol/water, $50: 50 \mathrm{~mL} / \mathrm{mL}$ ) $32-50 \mathrm{~min}$ and the rebalancing of the column from 51 to $65 \mathrm{~min}$ under the initial gradient conditions. For oligomeric procyanidins, a solvent gradient A (distilled water) and solvent B (water/acetic acid, $90: 10 \mathrm{~mL} / \mathrm{mL}$ ) was applied at a flow rate of $1.0 \mathrm{~mL} / \mathrm{min}$ as: $10-70 \%$ linear B 0-45 min, 70-90\%. Quantification of monomeric flavan-3-ol and oligomeric procyanidins (some dimers and trimers) was based on standard curves obtained with $(+)$ catechin for the monomers and B2 for the other compounds.

Separation of proanthocyanidins was carried out using Sep-Pak C18 cartridges (Waters, Milford, USA) and quantification of the fractions obtained employed the vanillin assay following the method of Sun, Leandro, Ricardo-da-Silva, and Spranger (1998). The wines were dealcoholized by rotary evaporation (BÜCHI Labortechnik, Flawil, Switzerland) at $<30{ }^{\circ} \mathrm{C}$ and adjusted to $\mathrm{pH} 7.0$ with phosphate buffer ( $\mathrm{pH}$ 7.0). This sample was then passed through the two preconditioned neutral Sep-Pak cartridges connected in series: the superior (tC18 SepPak) and the inferior (C18 Sep-Pak). Elution was carried out with $10 \mathrm{~mL}$ of $\mathrm{H}_{2} \mathrm{O}$ adjusted to $\mathrm{pH} 7.0$ to eliminate phenolic acids, then the cartridges were dried with $\mathrm{N}_{2}$, elutions were carried out first with $25 \mathrm{~mL}$ of ethyl acetate to elute catechins and oligomeric procyanidins, accompanied by some other small phenolic molecules (fractions F I and II), and then with $10 \mathrm{~mL}$ of methanol to elute the polymeric procyanidins and anthocyanins (FIII). For the separation of catechins from 
oligomeric procyanidins (FI+ II) was evaporated to dryness under vacuum at $25{ }^{\circ} \mathrm{C}$, dissolved in distilled water, and redeposited onto the same connected cartridges preconditioned with distilled water. After the cartridges were dried with $\mathrm{N}_{2}$, separation of catechins and oligomeric procyanidins was realized by sequential elution with $25 \mathrm{~mL}$ of diethyl ether (FI) and then with $10 \mathrm{~mL}$ of methanol (FII).

\subsection{Characterisation of wine sensory profile}

Sensory analysis was carried out by a panel of twelve experienced wine tasters. These evaluated the visual, olfactory and taste characteristics with Quantitative Descriptive Analysis (QDA), recording 16 attributes: four visual, five aromatic and seven taste. All parameters were quantified on a scale with unstructured intensity of 10 points, with minimum anchorage on the left and maximum on the right. The test room comprised individual, white, illuminated booths. Samples were served individually, coded in tasting glasses (ISO model) containing $50 \mathrm{~mL}$ and at a temperature of $18 \pm 2{ }^{\circ} \mathrm{C}$ (considered ideal for tasting red wines).

\subsection{Statistical analyses}

All chemical analyses were in triplicate. Analysis of variance (ANOVA) was used to detect significant differences between rootstocks and harvest seasons. Differences between treatments were tested by a multiple means comparison test (Tukey's HSD) $(P=0.05)$. Principal component analysis (PCA) was used with the data for anthocyanins, fractionation of condensed tannins (flavanols) and small flavanols to evaluate the effects of rootstocks and harvest seasons. Analyses were carried out in the STATISTIX 9.0 analytical software (Florida, USA).

\section{Results and discussion}

\subsection{Classic analysis}

Results of the analyses of the classic quality parameters of tropical red wines are presented in Table $1 \mathrm{pH}$ values ranged from 3.84 to 4.02 in the first semester on IAC 313 and from 3.95 to 3.98 on 1103P. In the second semester, the values were 3.91 on IAC 313 and 4.04 to 4.16 on 1103P. There was no significant effect of rootstock or semester on wine $\mathrm{pH}$. According to Pereira et al. (2018) $\mathrm{pH}$ values between 3.60 and 4.50 are observed in the region for wines of different varieties, which can be attributed to excessive use of potassium fertilisers, or to naturally high levels of soil potassium in the region.

There is a tendency for higher $\mathrm{pH}$ in the second semester grapes.
This may be related to the climatic conditions in this semester which falls over the summer season (higher temperatures, greater insolation, low thermal amplitude day/night), leading to increased acid degradation in the grapes and consequently in the wines.

Total acidity ranged from 4.3 to $5.1 \mathrm{~g} / \mathrm{L}$ on IAC313 and $4.6-5.7 \mathrm{~g} / \mathrm{L}$ on 1103P. Higher total acids on 1103P may be related to vigour on this rootstock. This fits with wines from the region of Minas Gerais, Brazil (Dias et al., 2017) where more vigorous rootstocks induced higher total acidity in Syrah wines.

Alcohol content ranged from 11 to $12.9 \% \mathrm{v} / \mathrm{v}$ in the study wines, being lower than that found for traditional regions, and is related to two main factors: first, during the study years (2014-2017), Brazilian legislation required a alcohol content of $8.5-14 \% \mathrm{v} / \mathrm{v}$ in wines made with Vitis vinifera L. (Brazil, 2014). Recently, in 2018, legislation was amended, allowing content between 14.1 and 16\% v/v (Brazil, 2018). Another factor is that the grapes from this area of the vineyard were used for production of young wines with low alcohol content and/or for blends with wines from other lots of the Company. In addition, in tropical conditions, companies seek to harvest grapes and produce wines with different alcoholic potentials and total acidity, then mix to correct and reduce the $\mathrm{pH}$, which are generally high. Thus, they mix with more or less acidic wines, more or less alcoholic, to keep the $\mathrm{pH}$ between 3.6 and 3.8, naturally, without adding tartaric acid, which is common and allowed by Brazilian and worldwide legislation (OIV, 2014).

\subsection{Potassium and calcium}

Potassium values are considered high in the wines made from grapes from the two rootstocks (Table 1). The wine potassium content on IAC 313 ranged from 1700 to $2423 \mathrm{mg} / \mathrm{L}$ and on 1103P it ranged from 1960 to $2068 \mathrm{mg} / \mathrm{L}$. When evaluating red wines from several regions of Brazil, Miele, Rizzon and Zanus (2010) also found high levels of potassium in their wine samples from the São Francisco Valley. There is a tendency for higher potassium concentrations in the second harvest season. This is possibly related to higher temperatures during both day and night, which increases photosynthesis, growth, enzymatic activity and vine water usage. According to some authors, potassium regulates these processes (Silva et al., 2014).

The highest calcium levels were in wines from grapes on IAC 313. In semesters 1 and 2, calcium concentrations were $80 \mathrm{mg} / \mathrm{L}$ and $62 \mathrm{mg} / \mathrm{L}$, respectively. The rootstock influenced calcium concentration of Syrah semiarid tropical wines. Rizzon and Miele (2017) when evaluated the effect of fifteen rootstocks on the mineral composition of Cabernet sauvignon wines, also verified a significant effect on the calcium

Table 1

Classical and mineral analyses in semiarid, tropical Syrah wines (Vitis vinifera L.) on different rootstocks and harvest seasons (semesters) in northeast Brazil. $a, b$

\begin{tabular}{|c|c|c|c|c|c|c|c|c|}
\hline Variety vs. Rootstock & Syrah - IAC 3 & & & & Syrah - 1103P & & & \\
\hline Year & 2016 & 2014 & 2017 & 2016 & 2016 & 2014 & 2017 & 2016 \\
\hline Harvest season & I semester & II semester & I semester & II semester & I semester & II semester & I semester & II semester \\
\hline \multicolumn{9}{|l|}{ Classic analysis } \\
\hline $\mathrm{pH}$ & $3.84^{\mathrm{c}} \pm 0.00$ & $3.91^{b c} \pm 0.00$ & $4.02^{\mathrm{ab}} \pm 0.00$ & $3.90^{\mathrm{bc}} \pm 0.1$ & $3.98^{\mathrm{ab}} \pm 0.00$ & $4.16^{\mathrm{a}} \pm 0.01$ & $3.95^{\mathrm{bc}} \pm 0.00$ & $4.04^{\mathrm{ab}} \pm 0.01$ \\
\hline Total acidity $(\mathrm{g} / \mathrm{L})$ & $5.1^{b} \pm 0.1$ & $5.1^{\mathrm{b}} \pm 0.1$ & $4.8^{\mathrm{bc}} \pm 0.0$ & $4.3^{\mathrm{d}} \pm 0.1$ & $4.8^{\mathrm{bc}} \pm 0.1$ & $5.7^{\mathrm{a}} \pm 0.1$ & $5.0^{\mathrm{b}} \pm 0.0$ & $4.6^{\mathrm{c}} \pm 0.1$ \\
\hline Volatile acidity (g/L) & $0.36^{c} \pm 0.0$ & $0.37^{c} \pm 0.0$ & $0.32^{c} \pm 0.0$ & $0.61^{\mathrm{ab}} \pm 0.0$ & $0.42^{\mathrm{c}} \pm 0.0$ & $0.65^{\mathrm{ab}} \pm 0.0$ & $0.35^{c} \pm 0.3$ & $0.81^{\mathrm{a}} \pm 0.0$ \\
\hline Alcohol content $(\% \mathrm{v} / \mathrm{v})$ & $11.0^{\mathrm{c}} \pm 0.0$ & $12.5^{\mathrm{ab}} \pm 0.0$ & $12.3^{\mathrm{b}} \pm 0.0$ & $12.4^{\mathrm{b}} \pm 0.1$ & $11.7^{\mathrm{c}} \pm 0.2$ & $12.3^{\mathrm{b}} \pm 0.0$ & $11.8^{\mathrm{c}} \pm 0.2$ & $12.9^{\mathrm{a}} \pm 0.1$ \\
\hline Total dry extract $(\mathrm{g} / \mathrm{L})$ & $25.7^{\mathrm{d}} \pm 0.0$ & $25.2^{\mathrm{d}} \pm 0.0$ & $30.2^{\mathrm{ab}} \pm 0.2$ & $22.4^{\mathrm{e}} \pm 0.2$ & $27.3^{\mathrm{c}} \pm 0.0$ & $29.7^{\mathrm{b}} \pm 0.2$ & $29.9^{\mathrm{ab}} \pm 0.1$ & $27.4^{\mathrm{c}} \pm 0.5$ \\
\hline Reducing substances (g/L) & $1.3^{\mathrm{b}} \pm 0.0$ & $1.6^{\mathrm{a}} \pm 0.1$ & $1.3^{\mathrm{b}} \pm 0.0$ & $1.2^{\mathrm{b}} \pm 0.1$ & $1.2^{\mathrm{b}} \pm 0.1$ & $1.4^{\mathrm{ab}} \pm 0.1$ & $1.4^{\mathrm{ab}} \pm 0.0$ & $1.1^{\mathrm{c}} \pm 0.0$ \\
\hline Free sulphur dioxide $(\mathrm{mg} / \mathrm{L})$ & $19^{\mathrm{f}} \pm 0.0$ & $27^{\mathrm{d}} \pm 2.6$ & $31^{\mathrm{bc}} \pm 0.0$ & $30^{\mathrm{c}} \pm 0.0$ & $31^{\mathrm{bc}} \pm 0.3$ & $33^{\mathrm{a}} \pm 0.0$ & $33^{\mathrm{a}} \pm 1.0$ & $25^{\mathrm{e}} \pm 0.6$ \\
\hline Total sulphur dioxide (mg/L) & $36^{\mathrm{h}} \pm 0.3$ & $50^{\mathrm{e}} \pm 0.1$ & $91^{\mathrm{a}} \pm 0.8$ & $64^{c} \pm 1.4$ & $40^{g} \pm 0.5$ & $48^{\mathrm{d}} \pm 0.0$ & $87^{\mathrm{b}} \pm 1.0$ & $43^{\mathrm{d}} \pm 1.0$ \\
\hline \multicolumn{9}{|l|}{ Minerals (mg/L) } \\
\hline Potassium & $1859^{\mathrm{e}} \pm 1.2$ & $2423^{\mathrm{a}} \pm 2.4$ & $1749^{\mathrm{f}} \pm 0.9$ & $1700^{\mathrm{f}} \pm 1.0$ & $2068^{c} \pm 1.8$ & $2282^{\mathrm{b}} \pm 2.7$ & $1960^{\mathrm{d}} \pm 1.4$ & $2051^{c} \pm 3.1$ \\
\hline Calcium & $67^{b} \pm 0.9$ & $42^{g} \pm 0.1$ & $80^{\mathrm{a}} \pm 1.3$ & $62^{\mathrm{b}} \pm 0.7$ & $55^{\mathrm{d}} \pm 0.5$ & $52^{\mathrm{e}} \pm 0.1$ & $54^{\mathrm{de}} \pm 0.1$ & $48^{\mathrm{f}} \pm 0.0$ \\
\hline
\end{tabular}

$a$ Means followed by the same letter in the lines did not differ by Tukey test at $5 \%\left(p^{<} 0.05\right) . b$ Legend: I (first); II (second), Total acidity ( $\mathrm{g} / \mathrm{L}$ of tartaric acid) and Volatile acidity ( $\mathrm{g} / \mathrm{L}$ of acetic acid). 
Table 2

Global phenolic compounds, colour, anthocyanins and other pigments in tropical Syrah wines - rootstock and harvest season (semester) effects. ${ }^{\text {ab }}$

\begin{tabular}{|c|c|c|c|c|c|c|c|c|}
\hline Variety vs. Rootstock & Syrah - IAC 313 & & & & Syrah - 1103P & & & \\
\hline Year & 2016 & 2014 & 2017 & 2016 & 2016 & 2014 & 2017 & 2016 \\
\hline Harvest season & I semester & II semester & I semester & II semester & I semester & II semester & I semester & II semester \\
\hline \multicolumn{9}{|c|}{ Global phenolic compounds } \\
\hline Total phenols (mg/L) & $1068.5^{\mathrm{e}} \pm 2.9$ & $1576.6^{\mathrm{b}} \pm 5.6$ & $1579.8^{\mathrm{b}} \pm 0.0$ & $1413.7^{\mathrm{c}} \pm 8.1$ & $1259.4^{\mathrm{d}} \pm 2.2$ & $1456.9^{c} \pm 6.5$ & $1385.7^{\mathrm{cd}} \pm 3.0$ & $2313.4^{\mathrm{a}} \pm 8.4$ \\
\hline Flavonoids (mg/L) & $917.5^{\mathrm{e}} \pm 3.1$ & $1415.8^{\mathrm{b}} \pm 4.4$ & $1435.3^{\mathrm{b}} \pm 4.8$ & $1253.6^{c} \pm 9.1$ & $1115.0^{\mathrm{d}} \pm 2.1$ & $1273.4^{\mathrm{c}} \pm 5.3$ & $1268.9^{\mathrm{c}} \pm 4.5$ & $2142.2^{\mathrm{a}} \pm 9.3$ \\
\hline Non-flavonoids (mg/L) & $151.6^{\mathrm{d}} \pm 2.1$ & $161.4^{\mathrm{c}} \pm 2.0$ & $144.0^{\mathrm{e}} \pm 2.0$ & $160.6^{\mathrm{c}} \pm 2.1$ & $145.0^{\mathrm{e}} \pm 1.3$ & $184.0^{\mathrm{a}} \pm 1.2$ & $118.3^{\mathrm{f}} \pm 1.2$ & $171.2^{\mathrm{b}} \pm 1.4$ \\
\hline \multicolumn{9}{|c|}{ Colour, anthocyanins and other pigments } \\
\hline $\begin{array}{l}\text { Total anthocyanins ( } \mathrm{mg} / \mathrm{L} \text { of } \\
\text { malvidin) }\end{array}$ & $209.0^{\mathrm{e}} \pm 6.0$ & $316.5^{\mathrm{b}} \pm 1.0$ & $240.5^{d} \pm 4.7$ & $190.8^{\mathrm{f}} \pm 9.0$ & $261.4^{c} \pm 4.0$ & $237.3^{\mathrm{d}} \pm 2.5$ & $205.8^{\mathrm{e}} \pm 4.0$ & $375.6^{\mathrm{a}} \pm 5.1$ \\
\hline $\begin{array}{l}\text { Coloured anthocyanins (mg/ } \\
\text { L of malvidin) }\end{array}$ & $19.3^{f} \pm 1.6$ & $41.5^{\mathrm{b}} \pm 0.3$ & $32.1^{\mathrm{d}} \pm 0.6$ & $22.9^{\mathrm{e}} \pm 1.4$ & $23.1^{\mathrm{e}} \pm 0.6$ & $35.0^{c} \pm 0.5$ & $19.5^{f} \pm 0.7$ & $46.4^{\mathrm{a}} \pm 2.3$ \\
\hline Ionisation index (\%) & $9.2^{\mathrm{d}} \pm 0.6$ & $12.3^{\mathrm{c}} \pm 1.1$ & $13.3^{\mathrm{b}} \pm 0.3$ & $12.0^{\mathrm{c}} \pm 0.2$ & $8.9^{\mathrm{e}} \pm 0.2$ & $14.8^{\mathrm{a}} \pm 0.3$ & $9.5^{\mathrm{d}} \pm 0.5$ & $12.4^{\mathrm{c}} \pm 0.5$ \\
\hline Total pigments (u.a.) & $11.6^{\mathrm{d}} \pm 0.3$ & $12.3^{\mathrm{c}} \pm 1.1$ & $15.3^{\mathrm{a}} \pm 0.2$ & $12.0^{\mathrm{c}} \pm 0.2$ & $14.5^{\mathrm{ab}} \pm 0.3$ & $14.8^{\mathrm{ab}} \pm 0.3$ & $9.5^{\mathrm{e}} \pm 0.5$ & $12.4^{\mathrm{c}} \pm 0.5$ \\
\hline Polymerised pigment (u.a.) & $0.7^{\mathrm{d}} \pm 0.0$ & $2.4^{\mathrm{a}} \pm 0.0$ & $2.0^{\mathrm{b}} \pm 0.0$ & $1.6^{\mathrm{c}} \pm 0.1$ & $0.9^{\mathrm{d}} \pm 0.0$ & $2.1^{\mathrm{b}} \pm 0.0$ & $1.6^{\mathrm{c}} \pm 0.0$ & $2.3^{\mathrm{ab}} \pm 0.1$ \\
\hline Polymerisation index (\%) & $5.8^{\mathrm{d}} \pm 0.5$ & $12.2^{\mathrm{b}} \pm 0.1$ & $12.9^{\mathrm{b}} \pm 0.3$ & $12.9^{\mathrm{b}} \pm 0.8$ & $6.0^{\mathrm{d}} \pm 0.3$ & $13.7^{\mathrm{a}} \pm 0.3$ & $12.2^{\mathrm{b}} \pm 0.2$ & $10.1^{\mathrm{c}} \pm 0.4$ \\
\hline Colour Intensity (u.a) & $3.303^{\mathrm{e}} \pm 0.02$ & $9.333^{\mathrm{a}} \pm 0.002$ & $7.043^{\mathrm{b}} \pm 0.090$ & $5.567^{c} \pm 0.039$ & $4.170^{\mathrm{d}} \pm 0.046$ & $7.897^{b} \pm 0.036$ & $5.233^{c} \pm 0.066$ & $9.507^{\mathrm{a}} \pm 0.165$ \\
\hline Tonality (u.a) & $0.799^{\mathrm{ab}} \pm 0.022$ & $1.329^{\mathrm{a}} \pm 0.015$ & $0.696^{c} \pm 0.003$ & $0.790^{c} \pm 0.013$ & $0.819^{\mathrm{a}} \pm 0.013$ & $1.320^{\mathrm{a}} \pm 0.004$ & $0.767^{\mathrm{b}} \pm 0.004$ & $0.762^{\mathrm{d}} \pm 0.013$ \\
\hline Co-pigmentation (\%) & $17.5^{\mathrm{b}} \pm 4.5$ & $19.5^{\mathrm{a}} \pm 0.5$ & $11.6^{\mathrm{d}} \pm 2.2$ & $14.0^{\mathrm{c}} \pm 2.5$ & $19.6^{\mathrm{a}} \pm 5.3$ & $12.1^{\mathrm{d}} \pm 0.9$ & $12.1^{\mathrm{d}} \pm 1.5$ & $9.1^{\mathrm{e}} \pm 2.4$ \\
\hline
\end{tabular}

$a$ Means followed by the same letter in the lines did not differ significantly by Tukey test at $5 \%\left(p^{<} 0.05\right)$. $b$ Legend.: I (first) and II (second).

contents.

Higher wine calcium on IAC 313 may be related to higher soil calcium uptake rates by this rootstock. Other authors have noted calcium accumulation can be related to scion and also to rootstock (Wooldridge, Louw, \& Conradie, 2010). The highest wine calcium concentrations were found in the first semester. This may be due to greater use of phytosanitary treatments against fungal diseases in the first semester when temperatures are around $27^{\circ} \mathrm{C}$ and rainfall is greater. A factor that may relate to the lower calcium concentration in wines in the second semester is the higher $\mathrm{pH}$ that favours calcium precipitation (Mckinnon, Scollary, Solomon, \& Williams, 1995).

\subsection{Global phenolic compounds}

Total phenols, flavonoid and non-flavonoid phenols in the wines are presented in Table 2, expressed in gallic acid, wines from vines on 1103P presented higher concentrations of phenolics. Total phenols were of $2313.4 \mathrm{mg} / \mathrm{L}$; flavonoids $2142.2 \mathrm{mg} / \mathrm{L}$ and non-flavonoid phenols $184.0 \mathrm{mg} / \mathrm{L}$. Total phenols were lower than reported by Gris et al. (2013) for Syrah wines (1103P) in the Santa Catarina region, where they found $2732.2 \mathrm{mg} / \mathrm{L}$ and $2790.5 \mathrm{mg} / \mathrm{L}$ in two consecutive years. Variation in the overall levels of phenolic concentration was significant, clearly the rootstock is not the only source of such variation. The amounts and types of the family of flavonoids (the largest group of total phenols) and non-flavonoids are also involved in reactions during vinification and wine aging (Balga, Leskó, Ladányi, \& Kállay, 2014; Fang et al., 2008), which may be related to lower concentrations of these compounds in the studied wines when compared to other wines of the same variety.

The effect of semester was more significant for the non-flavonoids, with a trend towards higher concentrations in the second semester. Concentrations ranged from 144.0 to $161.4 \mathrm{mg} / \mathrm{L}$ for samples of IAC 313 and $118.3-184.0 \mathrm{mg} / \mathrm{L}$ in wines 1103P. These compounds include phenolic, benzoic and cinnamic acids and also other phenolic derivatives such as stilbenes. The higher concentrations in the second harvest season may be related to the higher temperatures during this period (Table 1, supplementary material), that promote greater synthesis of hydroxybenzoic acids and stilbene as a vine response to climate stress. Increases in these compounds as a defence response to stress have also been noted by Teixeira, Eiras-Dias, Castellarin, and Gerós (2013).

\subsection{Colour, anthocyanins and other pigments}

Concentrations of total and coloured anthocyanins in the wine were higher onto 1103P (Table 2) but with a greater influence of semester than of rootstock. The concentrations of total anthocyanins in Syrah wines onto IAC 313 varied from 190.8 to $316.5 \mathrm{mg} / \mathrm{L}$ while onto $1103 \mathrm{P}$ the range was from 205.8 to $375.6 \mathrm{mg} / \mathrm{L}$ both expressed in malvidin 3$O$-glucoside. These concentrations were lower than those reported by Harbertson and Keller (2012) and Condurso et al. (2016) for Syrah wines in regions of traditional viticulture. The coloured anthocyanin concentrations ranged from 19.3 to $41.5 \mathrm{mg} / \mathrm{L}$ of malvidin 3-O-glucoside and from 19.5 to $46.4 \mathrm{mg} / \mathrm{L}$ of malvidin 3-O-glucoside in wines from plants on IAC 313 and 1103P, respectively.

The polymerised pigments were higher in the second harvest season, possibly due to a higher concentration of monomeric anthocyanins and proanthocyanidins. A reaction between anthocyanins and tannins extracted during fermentation may contribute to the formation of polymeric pigments (Bindon, Kassara, Hayasaka \& Schulkin, 2014; Es-Safi, Fulcrand, Cheynier, \& Moutounet, 1999).

Percentage of co-pigmentation (Table 2) varied between rootstocks and semesters. Wines from IAC 313 showed higher co-pigmentation in the second semester, while those from 1103P were higher in the first semester. This may be related to a greater synthesis of cofactors (phenolic acids, flavonols, flavones, amino acids and anthocyanins) in the grapes from each rootstock and in the different semesters but further investigation is required.

Concentrations of anthocyanins varied between rootstocks and harvest seasons, with no significant differences in total wine pigments, polymerised pigments, hue or colour intensity (Table 2). For wines on self-rooted Syrah vines and on Syrah vines grafted on 110 Richter, Mantilla et al. (2017) found higher concentrations of anthocyanins and pigments on the grafted vines. Dias et al. (2017) evaluated Syrah wines on different rootstocks and found wines from vines with the more vigorous rootstocks had slightly improved phenolic composition.

\subsection{Monomeric anthocyanins}

Among the fourteen anthocyanins measured (supplementary material - Table 3), five were significantly higher in wines from vines on IAC 313: petunidin $3-O$-acetylglucoside $(3.7 \mathrm{mg} / \mathrm{L})$, malvidin 3 - $O$-acetylglucoside $(17.8 \mathrm{mg} / \mathrm{L})$, peonidin $3-O$-coumarylglucoside $(1.4 \mathrm{mg} / \mathrm{L})$, petunidin 3 - $O$-coumarylglucoside $(2.0 \mathrm{mg} / \mathrm{L})$ and malvidin $3-O$ - 
coumarylglucoside $(4.4 \mathrm{mg} / \mathrm{L})$. In the second semester of 2014 , wines from grapes onto 1103P had higher levels of cyanidin 3-O-glucoside $(2.2 \mathrm{mg} / \mathrm{L})$ and cyanidin $3-O$-acetylglucoside $(2.6 \mathrm{mg} / \mathrm{L})$. The highest concentrations of malvidin 3-O-glucoside in the second semester of 2016 were $36.1 \mathrm{mg} / \mathrm{L}$ (IAC 313) and $34.4 \mathrm{mg} / \mathrm{L}$ (1103P), these concentrations were lower than the reported by other authors for Syrah wines from traditional regions, for example, Lingua, Fabani, Wunderlin, and Baroni (2016) detected $87.4 \mathrm{mg} / \mathrm{L}$ for Argentine wines and GilMuñoz Bautista-Ortín, Ruiz-García, Fernández-Fernández and Gómez -Plaza (2017) found $448.2 \mathrm{mg} / \mathrm{L}$ in Spanish wines. There were no significant differences between samples for the other anthocyanins. Here, the effects of rootstock on anthocyanin composition were small, variable and non-significant, in line with the findings of Harbertson and Keller (2012) for Syrah wines, five rootstocks (5C, $140 \mathrm{Ru}, 1103 \mathrm{P}$, 3309C, and 101CU) on Syrah wine composition in the Yakima Valley (USA).

Total monomeric anthocyanins ranged from 37.3 to $71.9 \mathrm{mg} / \mathrm{L}$ (IAC 313 ) and $41.1-71.3 \mathrm{mg} / \mathrm{L}$ (1103P). There was a trend for higher concentrations in the second harvest season, for wine samples (1103P). In general, the classes, proportions and quantities of anthocyanins in red grapes depend on cultivar, weather and viticultural practice, rather than on rootstock (Cortell, Halbleib, Gallagher, Righetti, \& Kennedy, 2007; Revilla, García-Beneytez, Cabello, Martín-Ortega, \& Ryan, 2001).

\subsection{Condensed tannins}

Concentrations of monomeric, oligomeric and polymeric tannins are shown in Table 3. These varied between semesters and rootstocks. It is reported that condensed tannin concentration of the wine depends on: the composition and amounts of tannins in the berries at harvest (Kennedy, Matthews, \& Waterhouse, 2000), on extraction processes and must composition (Sacchi, Bisson, \& Adams, 2005) and on interactions with polysaccharides (from grape skins) and mannoproteins and other polysaccharides from yeast (Bindon \& Kennedy, 2011; Hanlin; Hrmova, Harbertson \& Downey, 2010; Rodrigues, Ricardo-da-silva, Lucas, \& Laureano, 2012).

Monomeric flavanol contents of wines varied from 7.4 to $23.6 \mathrm{mg} / \mathrm{L}$ on IAC 313 and from 7.0 to $22.4 \mathrm{mg} / \mathrm{L}$ on $1103 \mathrm{P}$. The highest concentrations of oligomeric tannins were $183.0 \mathrm{mg} / \mathrm{L}$ on IAC 313 and $142.5 \mathrm{mg} / \mathrm{L}$ on 1103P. The polymeric tannins were higher onto 1103P $(791.9 \mathrm{mg} / \mathrm{L})$ and on IAC $313(787.1 \mathrm{mg} / \mathrm{L})$. The concentrations of oligomeric and polymeric tannins are similar to those reported by Cosme, Ricardo-da-Silva, and Laureano (2009) for a range of Vitis vinifera L. cultivars in Lisbon. For the first time, was presented results for flavanols characterised by fractionation, and these exhibit significant differences correlating with semester and rootstock.

Concentrations of total tannins varied between rootstocks and semester. On IAC 313 total tannins wines varied from 443.5 to $1037.7 \mathrm{mg} / \mathrm{L}$ while on $1103 \mathrm{P}$ levels varied from 617.8 to $887.3 \mathrm{mg} / \mathrm{L}$. In the majority of semesters, condensed tannins were highest on 1103P (except for the semester 2 harvest in 2014) when they were highest for Syrah wines IAC $313(1037.7 \mathrm{mg} / \mathrm{L})$. These findings agree with those of Harbertson and Keller (2012) who reported only minor rootstock effects of five rootstocks on Syrah wine tannins. The total condensed tannin concentrations varied significantly between harvest seasons. This agrees with Oliveira et al. (2018) in the same region, for wines cv. 'Touriga Nacional'. It would seem these differences are related first to the extraction of condensed tannins and then to their subsequent reactions during and after vinification and during aging. The value of total tannins in wines from IAC 313 in the second semester of 2014 was so high, as compared to other treatments. IAC 313 rootstock, produced by Campinas Agronomical Institute (IAC), in Brazil, is a very greater vigour rootstock and in that condition presented highest values, with high amounts of leaves and physiological activity (data not measured) when compared to the Paulsen 1103 in under the same conditions. In other vintages the values have also presented differences but not too much, even were significant.

Table 3 shows a relationship between total condensed tannins and tanning power (the aggregation of the tannin with protein). The more tannins in a wine the greater the tanning power (de Freitas \& Mateus, 2001).

Table 3

Condensed tannins, monomeric flavanols and small oligomeric procyanidins in tropical semiarid wines of Brazil - rootstock and harvest season effect.

\begin{tabular}{|c|c|c|c|c|c|c|c|c|}
\hline Variety vs. Rootstock & Syrah - IAC 313 & & & & Syrah - 1103P & & & \\
\hline Year & 2016 & 2014 & 2017 & 2016 & 2016 & 2014 & 2017 & 2016 \\
\hline Harvest season & I semester & II semester & I semester & II semester & I semester & II semester & I semester & II semester \\
\hline \multicolumn{9}{|l|}{ Condensed tannins } \\
\hline Monomeric & $20.2^{\mathrm{c}} \pm 1.4$ & $23.6^{\mathrm{a}} \pm 0.4$ & $16.7^{\mathrm{cd}} \pm 4.5$ & $7.4^{\mathrm{f}} \pm 0.8$ & $22.4^{\mathrm{b}} \pm 0.2$ & $16.3^{\mathrm{d}} \pm 0.4$ & $11.7^{\mathrm{e}} \pm 0.4$ & $7.0^{f} \pm 0.6$ \\
\hline Oligomeric & $35.5^{g} \pm 2.5$ & $183.0^{\mathrm{a}} \pm 5.9$ & $45.8^{\mathrm{f}} \pm 1.2$ & $41.1^{\mathrm{f}} \pm 1.0$ & $52.2^{\mathrm{e}} \pm 1.4$ & $142.5^{\mathrm{b}} \pm 0.5$ & $87.3^{c} \pm 1.6$ & $64.9^{\mathrm{d}} \pm 2.0$ \\
\hline Polymeric & $387.8^{\mathrm{f}} \pm 2.3$ & $787.1^{\mathrm{ab}} \pm 3.1$ & $579.3^{\mathrm{d}} \pm 1.8$ & $531.5^{\mathrm{e}} \pm 9.8$ & $543.2^{\mathrm{e}} \pm 7.7$ & $665.4^{\mathrm{c}} \pm 1.2$ & $791.9^{\mathrm{a}} \pm 3.5$ & $675.7^{c} \pm 8.9$ \\
\hline Total tannins & $443.5^{\mathrm{h}} \pm 3.1$ & $1037.7^{\mathrm{a}} \pm 6.7$ & $641.8^{e} \pm 8.6$ & $580.0^{g} \pm 3.2$ & $617.8^{\mathrm{f}} \pm 7.9$ & $824.2^{\mathrm{c}} \pm 1.5$ & $887.3^{b} \pm 4.4$ & $747.6^{\mathrm{d}} \pm 2.9$ \\
\hline \multicolumn{9}{|l|}{ Monomeric flavanols } \\
\hline$(+)$ catechin & $4.6^{\mathrm{c}} \pm 0.5$ & $3.3^{\mathrm{e}} \pm 0.1$ & $3.9^{\mathrm{d}} \pm 0.1$ & $4.2^{\mathrm{cd}} \pm 0.1$ & $4.0^{\mathrm{d}} \pm 0.2$ & $5.4^{\mathrm{b}} \pm 0.0$ & $3.5^{\mathrm{e}} \pm 0.0$ & $8.6^{\mathrm{a}} \pm 0.2$ \\
\hline$(-)$ epicatechin & $7.3^{c} \pm 0.1$ & $5.0^{\mathrm{e}} \pm 0.2$ & $6.4^{\mathrm{d}} \pm 0.0$ & $6.6^{\mathrm{d}} \pm 0.1$ & $6.2^{\mathrm{d}} \pm 0.6$ & $6.9^{\mathrm{cd}} \pm 0.0$ & $8.4^{\mathrm{b}} \pm 0.0$ & $12.6^{\mathrm{a}} \pm 0.2$ \\
\hline$(-)$ epicatechin 3-O-gallate & $0.3^{\mathrm{b}} \pm 0.1$ & $0.6^{\mathrm{ab}} \pm 0.0$ & $0.3^{\mathrm{b}} \pm 0.0$ & $1.0^{\mathrm{a}} \pm 0.0$ & $0.9^{\mathrm{a}} \pm 0.1$ & $0.9^{\mathrm{a}} \pm 0.0$ & $0.2^{\mathrm{b}} \pm 0.0$ & $0.4^{\mathrm{b}} \pm 0.1$ \\
\hline \multicolumn{9}{|l|}{ Procyanidin dimers } \\
\hline B1 & $8.5^{c} \pm 0.3$ & $9.8^{\mathrm{a}} \pm 0.0$ & $7.5^{\mathrm{d}} \pm 0.0$ & $8.3^{c} \pm 0.4$ & $6.9^{d} \pm 0.9$ & $4.0^{\mathrm{f}} \pm 0.2$ & $4.8^{\mathrm{e}} \pm 0.0$ & $9.2^{\mathrm{b}} \pm 0.1$ \\
\hline B2 & $10.7^{\mathrm{c}} \pm 0.1$ & $15.7^{\mathrm{b}} \pm 0.6$ & $8.4^{\mathrm{c}} \pm 0.1$ & $11.1^{\mathrm{c}} \pm 0.2$ & $8.7^{\mathrm{d}} \pm 0.5$ & $21.0^{\mathrm{a}} \pm 0.3$ & $7.4^{\mathrm{e}} \pm 0.5$ & $9.9^{d} \pm 0.2$ \\
\hline B3 & $1.4^{\mathrm{d}} \pm 0.0$ & $3.7^{\mathrm{b}} \pm 0.1$ & $1.9^{\mathrm{e}} \pm 0.1$ & $4.3^{\mathrm{a}} \pm 0.1$ & $2.3^{\mathrm{c}} \pm 0.4$ & $4.7^{\mathrm{a}} \pm 0.2$ & $4.4^{\mathrm{a}} \pm 0.1$ & $3.4^{\mathrm{b}} \pm 0.1$ \\
\hline B4 & $0.1^{\mathrm{d}} \pm 0.0$ & $5.0^{\mathrm{a}} \pm 0.8$ & $0.2^{\mathrm{d}} \pm 0.0$ & $3.1^{\mathrm{b}} \pm 0.1$ & $0.1^{\mathrm{d}} \pm 0.0$ & $0.0^{\mathrm{d}} \pm 0.0$ & $0.1^{\mathrm{d}} \pm 0.0$ & $1.1^{\mathrm{c}} \pm 0.0$ \\
\hline \multicolumn{9}{|l|}{ Procyanidin dimers gallate } \\
\hline B1 3-O-gallate & $0.5^{\mathrm{c}} \pm 0.1$ & $0.3^{\mathrm{c}} \pm 0.1$ & $0.3^{\mathrm{c}} \pm 0.0$ & $0.2^{\mathrm{c}} \pm 0.0$ & $0.6^{\mathrm{c}} \pm 0.0$ & $1.8^{\mathrm{a}} \pm 0.2$ & $1.1^{\mathrm{b}} \pm 0.0$ & $1.0^{\mathrm{b}} \pm 0.0$ \\
\hline B2 3-O-gallate & $0.4^{\mathrm{b}} \pm 0.1$ & $0.4^{\mathrm{b}} \pm 0.1$ & $0.3^{\mathrm{b}} \pm 0.0$ & $0.1^{\mathrm{c}} \pm 0.0$ & $0.5^{\mathrm{ab}} \pm 0.0$ & $0.6^{\mathrm{ab}} \pm 0.1$ & $0.1^{\mathrm{c}} \pm 0.0$ & $0.0^{\mathrm{c}} \pm 0.0$ \\
\hline B2 3'-O-gallate & $0.5^{\mathrm{de}} \pm 0.0$ & $0.9^{\mathrm{d}} \pm 0.1$ & $0.4^{\mathrm{de}} \pm 0.0$ & $1.3^{\mathrm{c}} \pm 0.5$ & $0.9^{\mathrm{d}} \pm 0.1$ & $6.0^{\mathrm{a}} \pm 0.2$ & $1.4^{\mathrm{c}} \pm 0.4$ & $4.1^{b} \pm 0.2$ \\
\hline \multicolumn{9}{|l|}{ Procyanidin trimers } \\
\hline $\mathrm{C} 1$ & $0.3^{\mathrm{c}} \pm 0.1$ & $2.1^{\mathrm{b}} \pm 0.3$ & $0.2^{\mathrm{c}} \pm 0.0$ & $3.1^{\mathrm{a}} \pm 0.1$ & $0.6^{\mathrm{c}} \pm 0.1$ & $0.2^{c} \pm 0.0$ & $0.7^{c} \pm 0.0$ & $0.5^{\mathrm{c}} \pm 0.1$ \\
\hline Trimer 2 & $1.9^{\mathrm{b}} \pm 0.1$ & $3.0^{\mathrm{a}} \pm 0.4$ & $1.5^{\mathrm{b}} \pm 0.0$ & $1.4^{\mathrm{b}} \pm 0.0$ & $2.5^{\mathrm{a}} \pm 0.4$ & $0.9^{c} \pm 0.0$ & $1.1^{\mathrm{c}} \pm 0.0$ & $2.6^{\mathrm{a}} \pm 0.1$ \\
\hline Total flavanols & $36.5^{\mathrm{d}} \pm 0.8$ & $49.8^{\mathrm{bc}} \pm 0.5$ & $31.3^{\mathrm{f}} \pm 0.6$ & $44.7^{c} \pm 0.8$ & $34.2^{\mathrm{e}} \pm 0.4$ & $52.4^{\mathrm{b}} \pm 0.2$ & $33.2^{\mathrm{f}} \pm 0.1$ & $53.4^{\mathrm{a}} \pm 0.6$ \\
\hline Tanning Power (NTU/mL) & $164.6^{\mathrm{de}} \pm 3.9$ & $240.5^{\mathrm{a}} \pm 9.0$ & $220.5^{b} \pm 8.0$ & $176.8^{d} \pm 7.0$ & $128.4^{\mathrm{f}} \pm 4.4$ & $212.1^{\mathrm{c}} \pm 1.8$ & $213.0^{c} \pm 4.0$ & $119.5^{f} \pm 2.6$ \\
\hline
\end{tabular}

$a b$ Means followed by the same letter in the lines did not differ by Tukey test at $5 \%$ ( $\mathrm{p}^{<} 0.05$ ). Legend: concentrations in $\mathrm{mg} / \mathrm{L}, \mathrm{I}$ (first) and II (second). 


\subsection{Monomeric flavanols and small oligomeric procyanidins}

Monomeric and small oligomeric flavanol concentrations are shown in supplementary material, Table 3 . The highest concentrations of the $(+)$-catechin $(6.6 \mathrm{mg} / \mathrm{L})$ and $(-)$-epicatechin $(12.6 \mathrm{mg} / \mathrm{L})$ monomer fractions on $1103 \mathrm{P}$ in the second semester. The (-)-epicatechin 3-Ogallate compounds ranged from 0.2 to $1.0 \mathrm{mg} / \mathrm{L}$, there are no differences between rootstocks or semesters.

Wines on IAC 313 had higher concentrations of B1 $(9.8 \mathrm{mg} / \mathrm{L})$ and B4 $(5.0 \mathrm{mg} / \mathrm{L})$ while those on 1103P had higher concentrations of B2 $(21.0 \mathrm{mg} / \mathrm{L}), \mathrm{B} 13$-O-gallate $(1.8 \mathrm{mg} / \mathrm{L})$ and $\mathrm{B} 23^{\prime}$-O-gallate $(6.0 \mathrm{mg} / \mathrm{L})$. Among the procyanidins trimers, C1 was higher on IAC $313(3.1 \mathrm{mg} / \mathrm{L})$. However, the concentration of trimer $2(0.9-3.0 \mathrm{mg} / \mathrm{L})$ was not significantly different between rootstocks or semesters.

Total flavanols were higher on 1103P (53.4 mg/L) and values were significantly higher in semester 2 . This is possibly related to the higher temperatures and lower day/night temperature differentials over this period. It resulted in a divergence between phenolic and technological maturation (mainly in seeds), providing a possible increase of tannins in wines. With the rapid technological maturation in the second semester, grapes are harvested with green seeds colour, which may favour the extraction of procyanidins for into wine. Further study is required to better understand tannin extraction in this terroir.

\subsection{Principal component analysis (PCA)}

Fig. 1A and B shows differences between wines from four harvest seasons and two rootstocks. Results are from monomeric anthocyanin analyses carried out using HPLC (supplementary material, Table 3). In addition to total phenols, the flavonoids, non-flavonoids, total and coloured anthocyanins and total and polymerised pigments, were all analysed spectrophotometrically (Table 2). The first two principal components explain $63.08 \%$ of total variability (PC1 vs. PC2), where PC1 explained $34.79 \%$ of variability and PC2 explained $28.29 \%$.

The first principal component separated samples in relation to semester 1 and 2 for all years. On the positive side of the $\mathrm{x}$-axis are the samples from the first semester, except for wines on IAC 313 in 2017, and on the negative side those on $1103 \mathrm{P}$ from the second semester of 2014 and 2016 vintages, those from both rootstocks. Separation was most influenced by total and polymeric pigments, flavonoids, total phenols, malvidin 3-O-coumarylglucoside and peonidin 3-O-acetylglucoside, which characterised wines from the second harvest season, of the 2014 and 2016 vintages.

In second principal component, on the positive side of the $\mathrm{x}$-axis in 2014, discriminated the samples in the second semester in both rootstocks. On the negative side of PC2 x-axis were wines from the second semester in 2016, also for both rootstocks. This evidenced a 'vintage effect', between years but in the same semester. This separation was most influenced by higher concentrations of cyanidin 3-O-glucoside, petunidin 3-O-acetylglucoside, cyanidin 3-O-acetylglucoside, petunidin 3-O-coumarylglucoside and non-flavonoids phenols in 2014. Wines from 2016 were characterised by higher amounts of petunidin 3-Oglucoside and malvidin 3-O-glucoside.

Fig. 2A and B shows discrimination among samples from the four vintages and the two rootstocks. Results are based on fractionation of condensed tannins and small oligomeric flavanols, analysed by HPLC (Table 3). The first two principal components (PC1 and PC2) explained $55.64 \%$ of total variability, where PC1 was responsible for $31.65 \%$ and PC2 for $23.99 \%$.

The PC1 separated samples mostly according to rootstock. In the
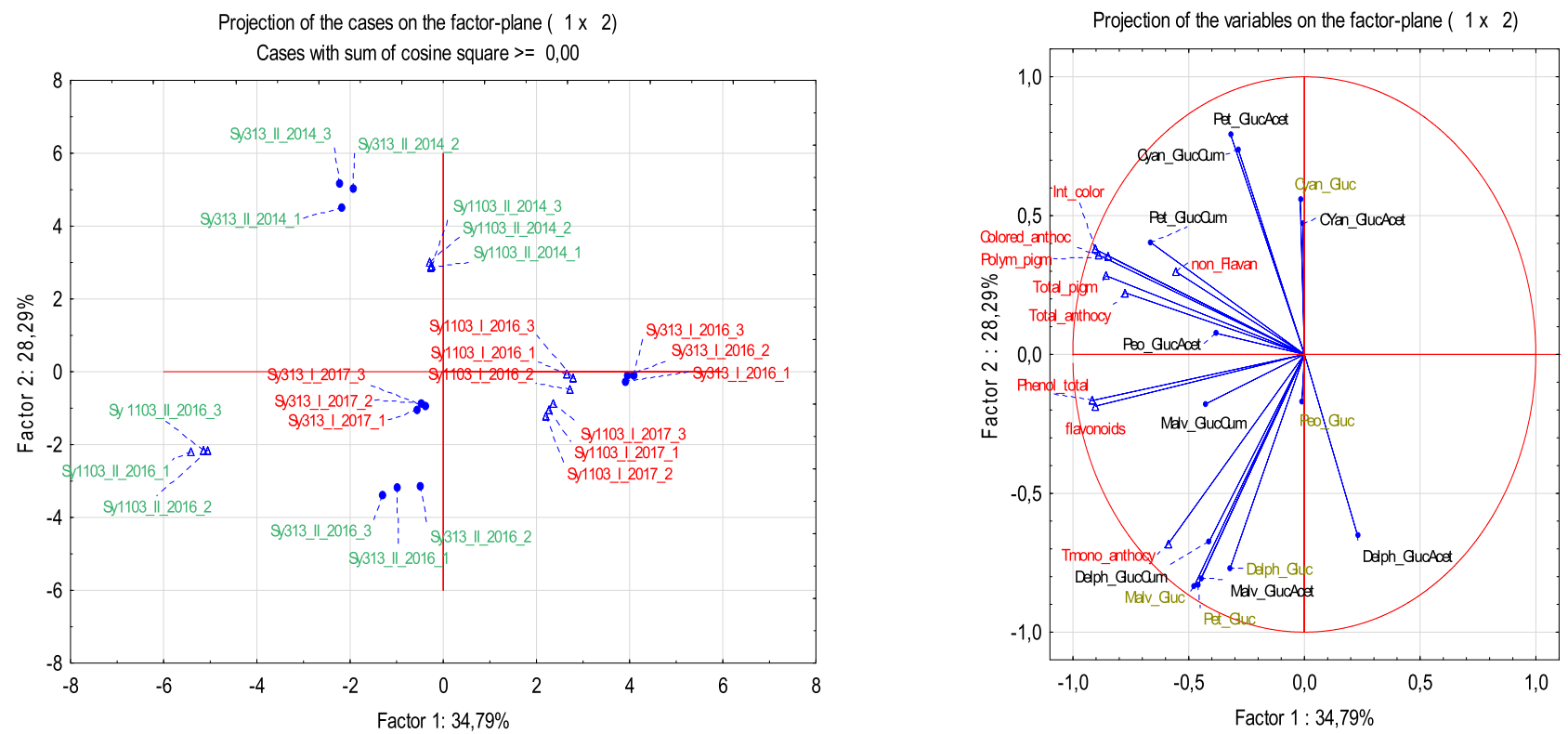

Fig. 1. Principal component analysis of the individual monomeric anthocyanins, total phenols, flavonoids and non-flavonoids in Syrah (Vitis vinifera L.) wines made with grapes on two rootstocks and over harvest seasons, in a tropical semiarid region of Brazil. All results are expressed as the average values of three replicates \pm standard deviation. Syrah 313_I (wines made with grapes from plants grafted on IAC 313 during the first semester in the years of 2016 and 2017); Syrah 313_II (wines made with grapes from plants grafted on IAC 313 during the second semester, in the years of 2014 and 2016). Syrah 1103_I (wines made from grapes of plants grafted on 1103P during the first semester of 2016 and 2017); Syrah 1103_II (wines made with grapes from plants grafted on 1103P during the second semester in the years of 2014 and 2016), Delph_gluc (delphinidin 3-O-glucoside), Cyan_gluc (cyanidin 3-O-glucoside), Petu_gluc (petunidin 3-O-glucoside), Peo_gluc (peonidin 3-O-glucoside), Malv_gluc (malvidin 3-O-glucoside), Delph_gluc_acet (delphinidin 3-O-acetylglucoside), Cyan_gluc_acet (cyanidin 3-O-acetylglucoside), Petu_gluc_acet (petunidin 3-O-acetylglucoside), Peo_gluc_acet (peonidin 3-O-acetylglucoside), Malv_gluc_acet (malvidin 3-O-acetylglucoside), Delph_gluc_pcum (delphinidin 3-O-coumarylglucoside), Cyan_gluc_pcum (cyanidin 3-O-coumarylglucoside), Petu_gluc_pcum (petunidin 3-O-coumarylglucoside), Peo_gluc_pcum (peonidin 3-O-coumarylglucoside), Malv_gluc_pcum (malvidin 3-O-coumarylglucoside), Flavon (flavonoids), Non-flavon (non-flavonoids), Total anthocy (total anthocyanins), Total anthoc HPLC (total monomeric anthocyanins). (For interpretation of the references to colour in this figure legend, the reader is referred to the Web version of this article.) 

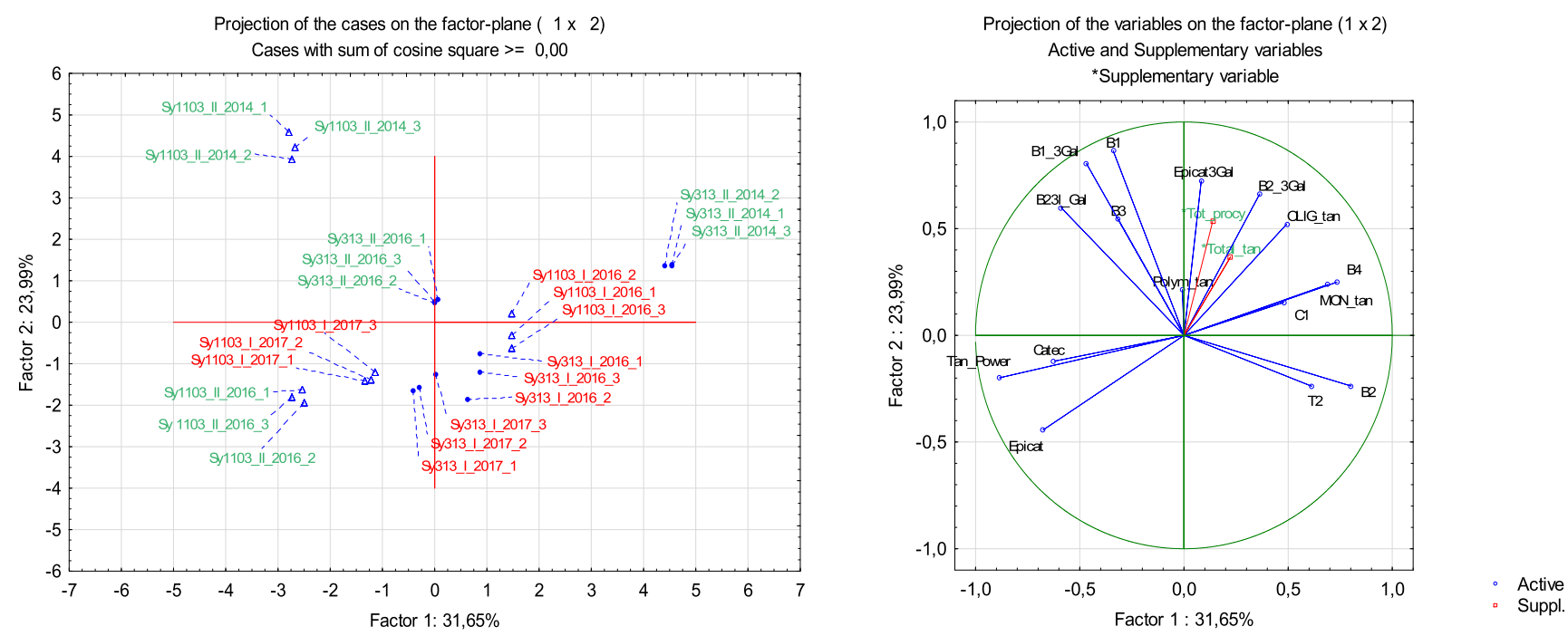

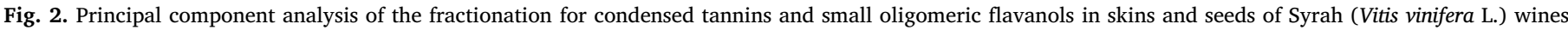

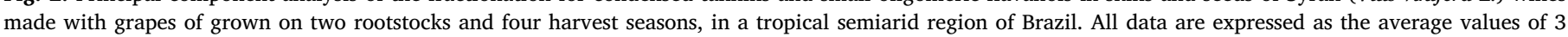

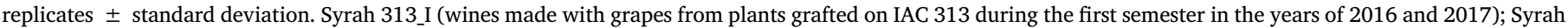

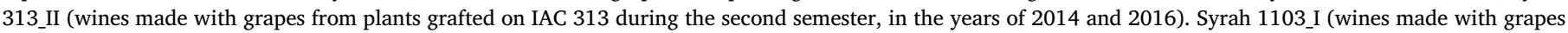

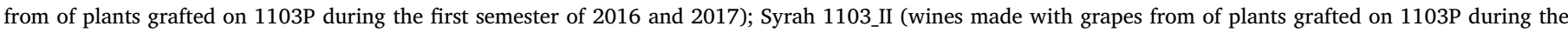

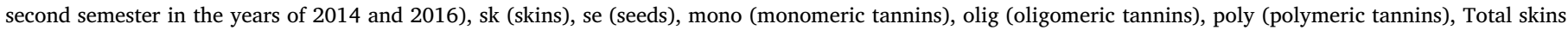

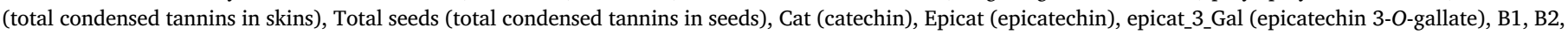

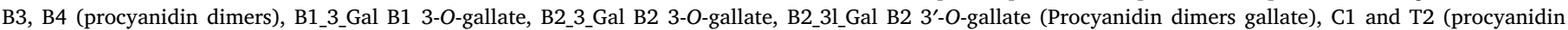
trimers).

positive side of the x-axis are the samples of Syrah wines on IAC 313 in the second semester of 2014, these being influenced by the monomeric tannins, B4 and B2 procyanidin dimers and trimer 2.

On the negative side of the $\mathrm{X}$-axis of PC1 are samples wines from vines on 1103P, in the second semester of 2014 and samples on 1103P, in the second semester of 2016. The separation of these samples was influenced mostly by catechin, epicatechin and tanning power.

The second principal component separated the samples in relation to the harvest season, with wine samples on 1103P, in the second semester of the 2014 vintage being on the positive side, and characterised by B1, B2 3-O-gallate, B2' 3-O-gallate and B3. On the negative side of the PC2 x-axis, were samples from the first semester, mainly Syrah wines on IAC 313 and 1103 P in 2017, IAC 313 in 2016 and on 1103P from semester 2 of 2016 and characterised by epicatechin and trimer 2 .

In the tropical conditions of the São Francisco Valley, harvest date is an important determinant of stability of the phenolic compounds. For example, red wines from grapes harvested between May to August can have more stable colour than those from grapes harvested between October to December. Wines from semester 2 can suffer earlier loss of colour and lower stability, browning just few months after bottling and thus having a shorter shelf life (unpublished data).

\subsection{Sensory characterisation}

The taster scores indicate an influence of rootstock on sensory profile (Table 4). From the 16 attributes evaluated, wines from grapes onto IAC 313 scored higher in 11 attributes, the other attributes were scored higher onto 1103P.

Fruity and spicy aromas scored higher on IAC 313, while floral, herbaceous and empyreumatic aromas scored higher on 1103P. A fruity aroma is characteristic of a young Syrah wine as mentioned by Zhao, Gao, Qian, and Li (2017) when evaluating wines in two regions of China - they reported more fruity aroma in Syrah wines from the north than from the south. Oliveira et al. (2011) also identified fruity aromas in Syrah wines of different clones, in the northeast, semiarid region of Brazil. Spicy aromas (mainly pepper) were also mentioned by Mayr et al. (2014) in characterising two premium Syrah wines from Australia using gas chromatography.

The Syrah wine onto IAC 313 scored high for sweetness, acidity, alcohol and astringency Table 4. For other taste attributes, such as sweetness, acidity and alcohol, it was not possible to correlate these with chemical and physicochemical factors such as $\mathrm{pH}$, total acidity, alcohol content, and reducing substances. This demonstrates how difficult it is to characterise a wine solely on chemical analyses, it being critical to include sensory analyses. This observation was made also by Sivilotti, Zulini, Peterlunger, and Petrussi (2007) when evaluating Cabernet Sauvignon wines from grapes and vines on various rootstocks.

Wine astringency is related to the quantity and types of tannins present. According to the chemical analyses, the wines scoring highest for astringency, Syrah onto IAC 313, are those with high concentrations of oligomeric tannins, total tannins and tanning power (Table 3). In particular, the astringency of tannins, which affects palatability, is reported to be related to the formation of complexes with salivary proteins. These may result in a decrease in lubricating properties of saliva and greater friction on mouth surfaces (Gawel, Oberholster, \& Leigh Francis, 2000).

As for the effect of semester on wine sensorial profile (Table 4) the notes varied among attributes according to year, there was no specific semester effect but there was a vintage effect. Especially for the first harvest season in 2017, with higher notes for fruity aroma, alcohol and persistence, regardless of rootstock; also for the second harvest season in 2014, with fruity aromas, spices and alcohol, regardless of rootstock.

\section{Conclusions}

Some compounds in Syrah wines from tropical semiarid region were influenced by rootstock and harvest season. In the classic physicochemical analyses, rootstock effects were not significant, with only small variations occurring between semesters.

Semester did influence wine composition with respect to calcium (semester 1), and with respect to alcohol content, total monomeric anthocyanins, non-flavonoids, polymerised pigments and total 
Table 4

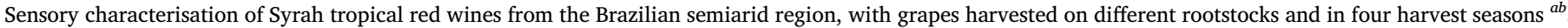

\begin{tabular}{|c|c|c|c|c|c|c|c|c|}
\hline Rootstock & IAC 313 & & & & $1103 P$ & & & \\
\hline Harvest season & 1st semester & & 2nd semester & & 1st semester & & 2nd semester & \\
\hline Years & 2016 & 2017 & 2014 & 2016 & 2016 & 2017 & 2014 & 2016 \\
\hline Colour & $3.6^{b} \pm 0.8$ & $7.3^{\mathrm{a}} \pm 0.6$ & $6.6^{\mathrm{a}} \pm 0.9$ & $7.5^{\mathrm{a}} \pm 1.7$ & $4.2^{c} \pm 0.6$ & $7.7^{\mathrm{a}} \pm 1.2$ & $6.0^{\mathrm{b}} \pm 0.8$ & $8.1^{\mathrm{a}} \pm 1.3$ \\
\hline Intensity & $0.7^{\mathrm{c}} \pm 0.3$ & $5.0^{\mathrm{ab}} \pm 0.9$ & $6.8^{\mathrm{a}} \pm 0.8$ & $3.9^{b} \pm 1.6$ & $2.7^{\mathrm{b}} \pm 1.0$ & $6.4^{\mathrm{a}} \pm 0.9$ & $4.9^{\mathrm{a}} \pm 1.6$ & $6.1^{\mathrm{a}} \pm 1.5$ \\
\hline Limpidity & $1.7^{\mathrm{b}} \pm 1.0$ & $2.7^{\mathrm{b}} \pm 1.0$ & $5.4^{\mathrm{a}} \pm 1.1$ & $1.9^{b} \pm 0.7$ & $3.6^{\mathrm{a}} \pm 1.2$ & $3.7^{\mathrm{a}} \pm 0.9$ & $3.4^{\mathrm{a}} \pm 1.6$ & $2.8^{\mathrm{a}} \pm 1.2$ \\
\hline Fluidity & $3.7^{c} \pm 1.4$ & $8.6^{a} \pm 0.9$ & $6.5^{b} \pm 0.9$ & $4.3^{c} \pm 1.2$ & $4.6^{\mathrm{ab}} \pm 1.1$ & $5.2^{\mathrm{ab}} \pm 0.5$ & $5.9^{\mathrm{a}} \pm 1.1$ & $5.2^{\mathrm{ab}} \pm 2.1$ \\
\hline Fruity & $2.5^{\mathrm{b}} \pm 1.1$ & $8.8^{\mathrm{a}} \pm 0.8$ & $7.4^{\mathrm{a}} \pm 0.7$ & $3.6^{\mathrm{b}} \pm 1.8$ & $3.0^{\mathrm{c}} \pm 1.2$ & $7.2^{\mathrm{a}} \pm 1.0$ & $5.3^{\mathrm{ab}} \pm 1.9$ & $4.3^{\mathrm{b}} \pm 1.8$ \\
\hline Floral & $1.8^{\mathrm{a}} \pm 0.5$ & $1.5^{\mathrm{a}} \pm 1.1$ & $2.1^{\mathrm{a}} \pm 1.4$ & $1.9^{\mathrm{a}} \pm 0.7$ & $3.1^{\mathrm{bc}} \pm 1.8$ & $5.5^{\mathrm{a}} \pm 1.2$ & $4.6^{\mathrm{ab}} \pm 1.6$ & $2.0^{\mathrm{c}} \pm 0.6$ \\
\hline Herbaceous & $3.7^{\mathrm{a}} \pm 0.8$ & $1.3^{\mathrm{b}} \pm 0.5$ & $1.1^{\mathrm{b}} \pm 0.8$ & $3.7^{\mathrm{a}} \pm 1.2$ & $4.4^{\mathrm{a}} \pm 1.0$ & $1.6^{b} \pm 0.6$ & $4.5^{\mathrm{a}} \pm 1.4$ & $3.2^{\mathrm{ab}} \pm 1.4$ \\
\hline Spices & $2.1^{b} \pm 1.3$ & $7.7^{\mathrm{a}} \pm 1.2$ & $6.0^{\mathrm{a}} \pm 2.0$ & $1.2^{\mathrm{b}} \pm 0.4$ & $4.2^{\mathrm{ab}} \pm 1.7$ & $1.2^{\mathrm{c}} \pm 0.8$ & $5.0^{\mathrm{a}} \pm 1.7$ & $2.2^{\mathrm{bc}} \pm 1.5$ \\
\hline Empyreumatic & $4.4^{\mathrm{a}} \pm 1.4$ & $2.8^{\mathrm{b}} \pm 1.1$ & $5.3^{\mathrm{a}} \pm 1.0$ & $2.8^{\mathrm{b}} \pm 1.0$ & $4.7^{\mathrm{ab}} \pm 1.2$ & $6.4^{\mathrm{a}} \pm 0.9$ & $3.8^{\mathrm{b}} \pm 1.5$ & $1.8^{\mathrm{c}} \pm 1.0$ \\
\hline Sweetness & $2.0^{\mathrm{bc}} \pm 1.1$ & $5.5^{\mathrm{a}} \pm 0.5$ & $3.3^{\mathrm{b}} \pm 1.4$ & $0.9^{c} \pm 0.6$ & $2.3^{b} \pm 0.6$ & $1.4^{\mathrm{b}} \pm 1.0$ & $4.6^{\mathrm{a}} \pm 1.2$ & $1.7^{\mathrm{b}} \pm 1.3$ \\
\hline Acidity & $4.0^{b} \pm 0.8$ & $6.2^{\mathrm{a}} \pm 0.9$ & $4.4^{\mathrm{b}} \pm 1.2$ & $4.0^{\mathrm{b}} \pm 1.2$ & $5.3^{\mathrm{a}} \pm 1.0$ & $4.3^{\mathrm{a}} \pm 2.4$ & $4.1^{\mathrm{a}} \pm 1.5$ & $3.4^{\mathrm{a}} \pm 1.0$ \\
\hline Alcohol & $2.4^{b} \pm 0.9$ & $7.4^{\mathrm{a}} \pm 0.8$ & $6.0^{\mathrm{a}} \pm 1.6$ & $3.1^{b} \pm 1.5$ & $3.4^{\mathrm{b}} \pm 1.1$ & $6.1^{\mathrm{a}} \pm 1.0$ & $5.2^{\mathrm{a}} \pm 1.9$ & $3.5^{\mathrm{b}} \pm 2.0$ \\
\hline Bitterness & $2.2^{\mathrm{a}} \pm 1.0$ & $2.9^{\mathrm{a}} \pm 1.1$ & $1.9^{\mathrm{a}} \pm 0.9$ & $2.5^{\mathrm{a}} \pm 1.2$ & $3.1^{\mathrm{a}} \pm 1.2$ & $4.2^{\mathrm{a}} \pm 1.3$ & $5.5^{\mathrm{a}} \pm 1.3$ & $2.8^{\mathrm{ab}} \pm 1.5$ \\
\hline Astringency & $2.4^{c} \pm 0.7$ & $5.3^{\mathrm{a}} \pm 1.0$ & $2.3^{c} \pm 1.6$ & $3.2^{\mathrm{b}} \pm 2.0$ & $2.6^{c} \pm 0.5$ & $6.8^{\mathrm{a}} \pm 0.9$ & $4.5^{\mathrm{b}} \pm 1.7$ & $4.5^{\mathrm{b}} \pm 2.3$ \\
\hline Body & $2.1^{\mathrm{c}} \pm 1.0$ & $4.7^{\mathrm{a}} \pm 1.4$ & $6.0^{\mathrm{a}} \pm 0.8$ & $3.3^{b} \pm 0.8$ & $2.9^{\mathrm{ab}} \pm 0.8$ & $4.4^{\mathrm{a}} \pm 1.2$ & $4.9^{\mathrm{a}} \pm 1.8$ & $4.2^{\mathrm{a}} \pm 1.3$ \\
\hline Persistence & $2.6^{\mathrm{a}} \pm 0.7$ & $5.9^{c} \pm 1.0$ & $6.0^{c} \pm 1.2$ & $3.7^{b} \pm 0.7$ & $3.2^{\mathrm{b}} \pm 0.7$ & $6.3^{\mathrm{a}} \pm 0.7$ & $4.6^{b} \pm 0.9$ & $4.4^{b} \pm 1.1$ \\
\hline Global appreciation & $3.3^{\mathrm{bc}} \pm 1.2$ & $4.8^{b} \pm 0.9$ & $6.1^{\mathrm{a}} \pm 1.0$ & $4.2^{\mathrm{b}} \pm 1.5$ & $4.1^{\mathrm{ab}} \pm 1.3$ & $5.1^{\mathrm{a}} \pm 1.1$ & $5.3^{\mathrm{a}} \pm 1.2$ & $4.3^{\mathrm{ab}} \pm 1.2$ \\
\hline
\end{tabular}

${ }^{a b}$ Statistic was performed considering the different harvest seasons for each rootstock, means followed by the same letter in the lines did not differ significantly by Tukey test at $5 \%\left(p^{<} 0.05\right)$, notes on a scale of $0-10$.

flavanols (semester 2).

Syrah wines on IAC 313 were favoured with higher concentrations of anthocyanins 3-O-acetylglucoside (petunidin and malvidin), anthocyanins 3-O-coumarylglucoside (malvidin, petunidin and peonidin), monomeric flavanols, oligomeric tannins, total condensed tannins and flavanols (B1, B4 and C1). Syrah wines on 1103P had higher concentrations of total anthocyanins, flavanols (catechin, epicatechin, B2, B1 3-O-gallate, B2 3'-O-gallate) and total flavanols.

The sensory profiles of the Syrah wines were influenced by rootstock followed by, mainly in relation to aromatic attributes. Syrah wines on IAC 313 were scored more highly by the tasters. The vintage effect was more significant than the semester effect for all samples, wines of the years of 2014 and 2017, with higher scores.

In tropical regions, such as the "sub-middle" of the São Francisco River Valley, the IAC 313 rootstock is more indicated than the Paulsen, even though the IAC is a more vigorous rootstock. Therefore, the opposite is recommended for temperate zones. Actually, to produce quality wines in temperate zones, rootstocks having less vigour are highly used.

The results indicate that the two different rootstocks can be used for the elaboration of different types of wines, such as the IAC 313 for guard red wines (with higher aging potential), and the Paulsen 1103 for young wines.

\section{Acknowledgments}

This research was supported by Brazilian companies: CAPES by scholarship of Oliveira, J. B. (Capes - 6070/1302); Embrapa Grape \& Wine and Semiarid; project CNPq (403438/2013-6) and the wine company "Santa Maria/Global Wines" (Lagoa Grande Municipality, Pernambuco).

In Portugal, we thank the research center in Instituto Superior de Agronomia: Linking Landscape, Environment, Agriculture and Food LEAF (UID/AGR/04129/2013) and FCT by scholarship of Egipto, R. (SFRH/BD/128847/2017).

\section{Appendix A. Supplementary data}

Supplementary data to this article can be found online at https://

\section{doi.org/10.1016/j.lwt.2019.108415.}

\section{References}

Balga, I., Leskó, A. M., Ladányi, M., \& Kállay, M. (2014). Influence of ageing on changes in polyphenolic compounds in red wines. Czech Journal of Food Sciences, 32(6), 563-569.

Bindon, K., Kassara, S., Hayasaka, Y., Schulkin, A., \& Smith, P. (2014). Properties of wine polymeric pigments formed from anthocyanin and tannins differing in size distribution and subunit composition. Journal of Agricultural and Food Chemistry, 62, $11582-11593$.

Bindon, K. A., \& Kennedy, J. A. (2011). Ripening-induced changes in grape skin proanthocyanidins modifies their interaction with cell-walls. Journal of Agricultural and Food Chemistry, 59, 2696-2707.

Boulton, R. (2001). The co-pigmentation of anthocyanins and its role in the color of red wine: A critical review. American Journal of Enology and Viticulture, 52, 67-80.

Brazil Decreto № 8198 de fevereiro de (2014). Produção, circulação e comercialização do vinho e derivados da uva e do vinho [Portuguese]. Decree No 8198 of February 2014. Production, circulation and commercialization of wine and grape derivatives and wine. [online]. Available at: http://www.agricultura.gov.br/assuntos/vigilanciaagropecuaria/ivegetal/bebidas-arquivos/decreto-no-8-198-de-20-de-fevereiro-de2014.pdf/view, Accessed date: 20 May 2019.

Brazil Instrução Normativa №14, fevereiro de (2018). Complementação dos padrões de qualidade do vinho e derivados da uva e do vinho [Portuguese]. Normative Instruction $N^{\circ}$ 14, February 2018. Complementation of the quality standards of wine and grape and wine derivatives. [online]. Available at: http://www.agricultura.gov.br/assuntos/ inspecao/produtos-vegetal/legislacao-1/biblioteca-de-normas-vinhos-e-bebidas/ instrucao-normativa-no-14-de-8-de-fevereiro-de-2018.pdf/view, Accessed date: 20 May 2019.

Condurso, C., Cincotta, F., Tripodi, G., Sparacio, A., Giglio, D. M. L., Sparla, S., et al (2016). Effects of cluster thinning on wine quality of Syrah cultivar (Vitis vinifera L.). European Food Research and Technology, 242, 1719-1726.

Cortell, J. M., Halbleib, M., Gallagher, A. V., Righetti, T. L., \& Kennedy, J. A. (2007). Influence of vine vigor on grape (Vitis vinifera L. cv. Pinot Noir) anthocyanins. 1. Anthocyanin concentration and composition in fruit. Journal of Agricultural and Food Chemistry, 55, 6575-6584.

Cosme, F., Ricardo-da-Silva, J. M., \& Laureano, O. (2009). Tannin profiles of Vitis vinifera L. cv. red grapes growing in Lisbon and from their monovarietal wines. Food Chemistry, 112, 197-204.

Dias, F. A. N., Mota, R. V., Souza, C. R., Pimentel, R. M. A., Souza, L. C., Souza, A. L., et al. (2017). Rootstock on vine performance and wine quality of 'Syrah' under double pruning management. Scientia Agricola, 74, 134-141.

Es-Safi, N. E., Fulcrand, H., Cheynier, H., \& Moutounet, M. (1999). Studies on the acetaldehyde-induced condensation of (-)-epicatechin and malvidin 3-O-glucoside in a model solution system. Journal of Agricultural and Food Chemistry, 47(5), 2096-2102.

Fang, F., Li, J. M., Zhang, P., Tang, K., Wang, W., Pan, Q. H., et al. (2008). Effects of grape variety, harvest date, fermentation vessel and wine ageing on flavonoid concentration in red wines. Food Research International, 41(1), 53-60.

de Freitas, V., \& Mateus, N. (2001). Structural features of procyanidin interactions with salivary proteins. Journal of Agricultural and Food Chemistry, 49, 940-945. 
Gawel, R., Oberholster, A., \& Leigh Francis, I. (2000). A mouth-feel wheel: Terminology for communicating the mouth-feel characteristics of red wine. Australian Journal of Grape and Wine Research, 6, 203-207.

Gil-Muñoz, R., Bautista-Ortín, A. B., Ruiz-García, Y., Fernández-Fernández, J. I., \& Gómez-Plaza, E. (2017). Improving phenolic and chromatic characteristics of Monastrell, Merlot and Syrah wines by using methyl jasmonate and benzothiadiazole. OENO One, 51(1), 17-27.

Gris, E. F., Mattivi, F., Vrhovsek, U., Filho, D. W., Pedrosa, R. C., \& Bordignon-Luiz, M. T. (2013). Phenolic profile and effect of regular consumption of Brazilian red wines on in vivo antioxidant activity. Journal of Food Composition and Analysis, 31, 31-40.

Hanlin, R., Hrmova, M., Harbertson, J. F., \& Downey, M. (2010). Review : Condensed tannin and grape cell-wall interactions and their impact on tannin extractability into wine. Australian Journal of Grape and Wine Research, 16, 173-188.

Harbertson, J. F., \& Keller, M. (2012). Rootstock effects on deficit-irrigated winegrapes in a dry 519 climate: Grape and wine composition. American Journal of Enology and Viticulture, 63, 40-48.

Kennedy, J. A., Matthews, M. A., \& Waterhouse, A. L. (2000). Changes in grape seed polyphenols during ripening. Phytochemistry, 55, 77-85.

Kramling, T. E., \& Singleton, V. L. (1969). An estimate of the non-flavanoid phenol in wines. American Journal of Enology and Viticulture, 20, 86-92.

Lingua, M. S., Fabani, M. P., Wunderlin, D. A., \& Baroni, M. V. (2016). In vivo antioxidant activity of grape, pomace and wine from three red varieties grown in Argentina: Its relationship to phenolic profile. Journal of Functional Foods, 20, 332-345.

Mantilla, S. M. O., Collins, C., Iland, P. G., Kidman, C. M., Ristic, R., Boss, ... Bastian, S. E. P. (2017). Shiraz (Vitis vinifera L.) berry and wine sensory profiles and composition are modulated by rootstocks. American Journal of Enology and Viticulture, 69, 32-44. https://doi.org/10.5344/ajev.2017.17017.

Maraš, V., Kodžulović, V., Raičević, J., Gazivoda, A., \& Perišić, M. (2016). Influence of different rootstocks on grape and wine quality of Montenegrin autochthonous grapevine cultivar 'Vranac'. Acta Horticulturae, 1136, 45-50. https://doi.org/10. 17660/ActaHortic.2016.1136.7.

Mayr, C. M., Geue, J. P., Holt, H. E., Pearson, W. P., Jeffery, D. W., \& Francis, I. L. (2014). Characterization of the key aroma compounds in shiraz wine by quantitation, aroma reconstitution, and omission studies. Journal of Agricultural and Food Chemistry, 62, $4528-4536$.

Mckinnon, A. J., Scollary, G. R., Solomon, D. H., \& Williams, P. J. (1995). The influence of wine components on the spontaneous precipitation of calcium $\mathrm{L}(+)$-tartrate in a model wine solution. American Journal of Enology and Viticulture, 46, 509-517.

Miele, A., Rizzon, L. A., \& Zanus, M. C. (2010). Discrimination of Brazilian red wines according to the viticultural region, varietal, and winery origin. Ciência e Tecnologia de Alimentos, 30, 268-275.

Monagas, M., Gómez-Cordovés, C., Bartolomé, B., Laureano, O., \& Ricardo-da-Silva, J. M. (2003). Monomeric, oligomeric and polimeric flavan-3-ol composition of wines and grapes from Vitis vinifera L. cv. Graciano, Tempranillo and Cabernet Sauvignon. Journal of Agricultural and Food Chemistry, 51, 6475-6481.

O.I.V (2014). Recueil des methodes internacionales d'analyse des vins et des moûts [French]. Compendium of international methods of analysis of wines and musts. Paris, France: Office International de la Vigne et du Vin.

Oliveira, J. B., Araújo, A. J. de B., Silva, G. G., Oliveira, V. de S., Nascimento, R. L., \& Pereira, G. E. (2011). Influence of rootstock on chemical characteristics of Syrah wines from Northeast Brazil. Anais of $3^{\text {rd }}$ international symposium on tropical wine 1218 november 2011, chiang mai, Thailand.

Oliveira, J. B., Faria, D. L., Duarte, D. F., Egipto, R., Laureano, O., Castro, R., ... Ricardoda-Silva, J. M. (2018). Effect of the harvest season on phenolic composition and oenological parameters of grapes and wines cv. 'Touriga Nacional' (Vitis vinifera L.) produced under tropical semi-arid climate, in the state of Pernambuco, Brazil. Ciência e Técnica Vitivinícola, 33(2), 145-166.

Ough, C. S., Cook, J. A., \& Lider, L. A. (1968). Rootstock-scion interactions concerning wine making. II. Wine compositional and sensory changes attributed to rootstock and fertilizer level differences. American Journal of Enology and Viticulture, 19, 254-265.

Pereira, G. E., Araújo, A. J. B., Santos, J., Vanderlinde, R., \& Lima, L. L. A. (2011) Chemical and aromatic characteristics of Brazilian tropical wines. Acta Horticulturae, 910, 135-140.

Pereira, G. E., Guerra, C. C., Amorim, F. F., Nascimento, A. M. S., Souza, J. F., Lima, L. L. A., ... Tonietto, J. (2018). Vinhos Tropicais do Semiárido do Brasil. Desvendando o Potential Vitivinícola desta Nova Fronteira Geográfica do Vinho [Portuguese]. SemiArid tropical wines of Brazil. Discovering the wine potential of this new geographic frontier of wine. Territoires du Vin: Vol. 9, (pp. 1-13). Université de Bourgogne, Dijon-
France 2018

Revilla, E., García-Beneytez, E., Cabello, F., Martín-Ortega, G., \& Ryan, J. M. (2001). Value of high-performance liquid chromatographic analysis of anthocyanins in the differentiation of red grape cultivars and red wines made from them. Journal of Chromatography A, 915, 53-60.

Ribéreau-Gayon, P. (1970). Le dosage des composés phénoliques totaux dans les vins rouges. [French]. The determination of total phenolic compounds in red wines. Analytica Chimica Acta, 52, 627-631.

Ribéreau-Gayon, P., \& Stonestreet, E. (1965). Dosage des tannins du vin rouge et determination de leur structure [French]. Determination of the tannins of red wine and determination of their structure. Analytica Chimica Acta, 2, 627-631.

Ricardo-da-Silva, J. M., Rigaud, J., Cheynier, V., Cheminat, A., \& Moutounet, M. (1991) Procyanidin dimers and trimers from grape seeds. Phytochemistry, 30, 1259-1264.

Ricardo-da-Silva, J. M., Rosec, J. P., Bourzeix, M., \& Heredia, N. (1990). Separation and quantitative determination of grape and wine procyanidins by high-performance reversed-phase liquid chromatography. Journal of the Science of Food and Agriculture, 53, 85-92.

Rigaud, J., Pérez-Ilzarbe, J., Ricardo-da-Silva, J. M., \& Cheynier, V. (1991). Micro method for the identification of proanthocyanidin using thiolysis monitored by high performance liquid chromatography. Journal of Chromatography A, 540, 401-405.

Rizzon, L. A., \& Miele, A. (2017). Rootstock effect on the mineral composition of Cabernet Sauvignon wine. Revista Brasileira Viticultura e Enologia, 9, 66-73.

Rodrigues, A., Ricardo-da-silva, J. M., Lucas, C., \& Laureano, O. (2012). Effect of commercial mannoproteins on wine colour and tannins stability. Food Chemistry, 131(3), 907-914.

Roggero, J. P., Coen, S., \& Ragonnet, B. (1986). High performance liquid chromatography survey on changes in pigment content in ripening grapes of Syrah. An approach to anthocyanin metabolism. American Journal of Enology and Viticulture, 37, 77-83.

Sacchi, K. L., Bisson, L. F., \& Adams, D. O. (2005). A review of the effect of winemaking techniques on phenolic extraction in red wines. American Journal of Enology and Viticulture, 56, 3.

Silva, D. J., Silva, A. O., Bassoi, L. H., Souza, D. R. M., Santos, L. M., \& Barbosa, B. D. R. (2014). Dynamics of potassium in the soil cultivated with fertirrigated vine: 1 st growing season. II INOVAGRI international meetinghttps://doi.org/10.12702/ii. inovagri.2014-a681.

Sivilotti, P., Zulini, L., Peterlunger, E., \& Petrussi, C. (2007). Sensory properties of 'Cabernet Sauvignon' wines as affected by rootstock and season. Acta Horticulturae, 754, 443-448. https://doi.org/10.17660/ActaHortic.2007.754.58.

Somers, T. C., \& Evans, M. E. (1977). Spectral evaluation of young red wines: Anthocyanin equilibria, total phenolic, free and molecular SO2 «chemical age». Journal of the Science of Food and Agriculture, 28, 279-287.

Sun, B. S., Leandro, M. C., Ricardo-da-Silva, J. M., \& Spranger, M. I. (1998). Separation of grape and wine proanthocyanidins according to their degree of polymerisation. Journal of Agricultural and Food Chemistry, 46, 1390-1396.

Suriano, S., Alba, V., Di Gennaro, D., Suriano, M. S., Savino, M., \& Tarricone, R. (2016) Genotype/rootstocks effect on the expression of anthocyanins and flavans in grapes and wines of Greco Nero n. (Vitis vinifera L.). Scientia Horticulturae, 209, 309-315.

Teixeira, A., Eiras-Dias, J., Castellarin, S. D., \& Gerós, H. (2013). Berry phenolics of grapevine under challenging environments. International Journal of Molecular Sciences, 14, 18711-18739.

Wooldridge, J., Louw, P. J. E., \& Conradie, W. J. (2010). Effects of rootstock on grapevine performance, petiole and must composition, and overall wine score of Vitis vinifera cv. Chardonnay and Pinot noir. South African Journal for Enology \& Viticulture, 31, 45-48.

Xu, X., Cheng, G., Duan, L., Jiang, R., Pan, Q., Duan, C., et al. (2015). Effect of training systems on fatty acids and their derived volatiles in Cabernet Sauvignon grapes and wines of the north foot of Mt. Tianshan. Food Chemistry, 181, 198-206.

Zhao, P., Gao, J., Qian, M., \& Li, H. (2017). Characterization of the key aroma compounds in Chinese Syrah wine by Gas Chromatography-Olfactometry-Mass Spectrometry and aroma reconstitution studies. Molecules, 22, 104.

\section{Further reading}

Ribéreau-Gayon, P., Glories, Y., Maujean, A., \& Dubourdieu, D. (2006). Phenolic compounds. P. The chemistry of wine stabilization and treatments. Handbook of Enology. Vol. 2. Chichester: John Wiley \& Sons Ltd. 